\title{
Effect of Polymer Seed Coating with Micronutrients on Soybeans in Southeastern Coastal Plains
}

\author{
Pawel Wiatrak \\ School of Agricultural, Forest and Environmental Sciences, \\ Clemson University, Edisto REC, Blackville, USA
}

Received 2013-09-24, Revised 2013-10-20; Accepted 2013-10-28

\begin{abstract}
Polymer seed coating with micronutrients may affect soybean (Glycine max (L.) Merr) growth and yields under dryland conditions. The objective of this study was to determine the effect of two seed application rates (265 and $395 \mathrm{~mL} 100 \mathrm{~kg} \mathrm{seeds}^{-1}$ ) of polymer based mixture of Copper $(\mathrm{Cu})$, Manganese (Mn) and Zinc (Zn) micronutrients on dryland soybeans near Blackville, SC from 2011 to 2012. Soybeans were evaluated for plant Normalized Difference Vegetation Index (NDVI), Leaf Area Index (LAI), plant height, seed weight and grain yields. Compared to untreated control, polymer seed coating significantly increased grain yields by 8.1 and $14.0 \%$ with seed applications at 265 and 395 $\mathrm{mL} 100 \mathrm{~kg} \mathrm{seeds}{ }^{-1}$, respectively. Plant NDVI improved by $10.5 \%$ with application of polymer seed coating treatment at $395 \mathrm{~mL} 100 \mathrm{~kg} \mathrm{seeds}^{-1}$. Seed coating at 265 and $395 \mathrm{~mL} 100 \mathrm{~kg} \mathrm{seeds}{ }^{-1}$ significantly increased plant NDVI by 10.2 and $10.8 \%$ at 8 weeks after soybean planting and 4.6 and $4.2 \%$ at 12 weeks after planting. Based on significant linear relationships, grain yields increased by $179.2 \mathrm{~kg} \mathrm{ha}^{-1}$ with increasing plant NDVI by 0.1 unit at 6 weeks after planting soybeans and $99.4 \mathrm{~kg}$ $\mathrm{ha}^{-1}$ with increasing weight by $1 \mathrm{~g}$ of 100 seeds. Treatment application did not affect plant NDVI at 4 through 6 and 9 weeks after planting, plant LAI at 8 and 12 weeks after planting and plant height. These results indicate that polymer seed coating may help to improve some growth parameters and grain yields of soybean under dryland conditions in Southeastern Coastal Plains.
\end{abstract}

Keywords: Soybean, Polymer, Seed Coating, Micronutrients, Normalized Difference Vegetation Index (NDVI), Leaf Area Index (LAI)

\section{INTRODUCTION}

Micronutrient deficiency in the soil, enhanced by excessive rain or application of fertilizers, leads to drastically reduced yields (Konkol et al., 2012). Xie et al. (2011) noted that applications of Nitrogen (N), Phosphorus (P) and Potassium (K) fertilizers affected soil properties, where $\mathrm{N}$ increased corn shoot $\mathrm{Cu}$ concentration and $\mathrm{P}$ decreased availability of Copper $(\mathrm{Cu})$ and Lead $(\mathrm{Pb})$. Wozniak and Makarski (2012) reported that $90 \mathrm{~kg} \mathrm{~N}^{-1}$ improved uptake of $\mathrm{K}$, Iron $(\mathrm{Fe})$, Zinc $(\mathrm{Zn})$ and $\mathrm{Cu}$, while high rates at $150 \mathrm{~kg} \mathrm{~N} \mathrm{ha}^{-1}$ increased concentrations of grain Manganese (Mn) in wheat (Triticum aestivum L.).

Although $\mathrm{P}$ may help increase grain yield, excess of this nutrient decreased $\mathrm{Zn}$ and enhanced $\mathrm{Fe}, \mathrm{Cu}$ and
Mn uptake in wheat biomass (Zhang et al., 2012). Hassan et al. (2012) observed increased P uptake in cereal crops planted after legumes.

Deficiencies of $\mathrm{Zn}, \mathrm{Fe}$ and $\mathrm{Fe}$ decrease wheat yields in light soils, so application of these micronutrients may help to increase yields of susceptible wheat cultivars (Narwal et al., 2012). Micronutrients $\mathrm{Fe}$ and $\mathrm{Mn}$ are important to plants, but antagonistic relationship between these nutrients may occur during uptake (Moosavi and Ronaghi, 2011). Kobraee and Shamsi (2011a) noted that micronutrient concentrations changed during growing season of soybeans from R1 (beginning bloom) to R8 (full maturity) stages with $\mathrm{Fe}$ decreasing in leaves and stems faster than other nutrients. Micronutrients $\mathrm{Zn}$, Fe and Mn were translocated from stems to leaves and 
Fe moved to seeds when soybeans were getting closer to R8 stage (Kobraee and Shamsi, 2011b).

Nutrient availability also depends on production practices. Ciolek et al. (2012) observed that wheat from organic farming had greater concentrations of $\mathrm{Mn}, \mathrm{Fe}$, $\mathrm{Zn}$, calcium $(\mathrm{Ca})$ and magnesium $(\mathrm{Mg})$ than conventional program. The N, P, K, Mg, Mn, $\mathrm{Zn}$ and $\mathrm{Cu}$ nutrients in wheat were higher after inoculating grains with different bacteria (Eleiwa et al., 2012).

Deficiency of $\mathrm{Zn}$ is a common problem in different regions (Ghandilyan et al., 2012). Optimum soybean yield can be obtained when $\mathrm{Zn}$ and $\mathrm{P}$ concentrations in the soil are greater than extension recommendations (Anthony et al., 2012a). Han et al. (2011) added that soybean growth was mostly positively correlated with $\mathrm{Zn}$ fertilizer. Soybean yield increased with $\mathrm{Zn}$ fertilization, even in soils at above critical levels, so recommendations for $\mathrm{Zn}$ need to be revised (Inocencio et al., 2012).

Sulfur (S) and $\mathrm{Fe}$ affected $\mathrm{Zn}$ and $\mathrm{Cu}$ uptake in wheat grain (Wang et al., 2013). Nadim et al. (2012) pointed out that wheat production was improved with Boron (B) and $\mathrm{Fe}$ fertilization. Beside foliar sprays, seed coatings also improved Zn uptake and soybean yields (Han et al., 2011). Guareschi et al. (2011) reported that polymer coating of superphosphate and potassium chloride 15 days prior to planting increased dry matter and grain yields while no significant differences were reported with polymer applications at planting. According to De Figueiredo et al. (2012), polymer-coated Monoammonium Phosphate (MAP) increased corn production. Additionally, seed coatings with temperature-activated polymer may help to protect seeds against cold soils (Gesch et al., 2012).

Growers need to better understand factors, which affect soybean yield variability (Anthony et al., 2012a). Anthony et al. (2012b) noted that fertilizer recommendations rely on estimating nutrients supplied and immobilized in the soil, which is important for sitespecific nutrient management. Micronutrients use in the fertilization program becomes a common practice on farms, but it is important to conduct more studies (Goncalves et al., 2011). There is a need to determine required micronutrient concentrations in soils and plants for soils with likely deficiencies (Hitsuda et al., 2010). Little research focused on seed polymer nutrient coating in soybeans under dryland environments and mostly insufficient rainfall. According to De Figueiredo et al. (2012), polymer-coated fertilizer need to be evaluated for improving efficiency of nutrients. Therefore, objective of this study was to evaluate polymer micronutrient seed coating on soybeans under dryland conditions in Southeastern Coastal Plains.

\section{MATERIALS AND METHODS}

\subsection{Site Preparation and Management}

This study was conducted on Dothan loamy sand (fine loamy, kaolinitic, thermic Plinthic Kandiudult) at Clemson University, Edisto Research and Education Center (REC) near Blackville, SC (33 21' $\left.\mathrm{N}, 81^{\circ} 19^{\prime} \mathrm{W}\right)$ under dryland conditions in 2011 and 2012. These are deep, well drained soils with slow permeability and soil $\mathrm{pH}$ was 6.2. Treatments consisted of 2 rates of $45 \%$ seed coating formulations with $\mathrm{Cu}, \mathrm{Mn}$ and $\mathrm{Zn}$ mixture on a polymer backbone at 265 and $395 \mathrm{~mL} 100 \mathrm{~kg}$ seeds $^{-1}$ and an untreated control.

Prior to planting soybeans following winter wheat, soybean seeds were treated with polymer seed coating formulations. Soybean cv. 'Pioneer 97M50' was planted at 272,000 seeds $\mathrm{ha}^{-1}$ in strip-till using Univerferth Ripper-Stripper (Unverferth Mtg. Co., Inc., Falida, OH) implement and John Deere 1700 MaxEmerge XP vacuum planters (John Deere Co., Moline, IL) on 27 May 2011 and 13 June 2012. The plot size was $6.1 \mathrm{~m}$ long by $4.0 \mathrm{~m}$ wide with four soybean rows. Pest control was based on the South Carolina Extension recommendations.

\subsection{Plant Measurements}

Plant measurements were conducted in the center of each plot. Normalized Difference Vegetation Index (NDVI) was measured using handheld GreenSeeker ${ }^{\mathrm{TM}}$ (NTech Industries, Inc. Ukiah, CA) instrument once a week starting at 4 weeks after planting. The Leaf Area Index (LAI) LAI-2000 (Li-Cor, Lincoln, NE) meter was used to measure plant index at 8 and 12 weeks after soybean planting. Ten random plants were selected for height measurements from the ground to the top of the plant prior to soybean harvest.

Soybeans were harvested from the entire length of the plot using Kinkaid 8XP small plot combine (Kinkaid Equip. Mtg, Haven, KS) on 8 November 2011 and 29 October 2012. Grain samples from all harvested plots were evaluated for weight and tested for moisture using a Burrows Model 750 Digital Moisture Computer (Seedburo Equip. Co., Chicago, IL). Seed weight was determined after counting seeds using the Agriculex electronic seed counter model ESC-1 (Agriculex Inc., Guelph, Ont., Canada). Grain yield was converted to $15.5 \%$ moisture content. Additionally, weather data (air temperature and precipitation) were recorded during soybean vegetation using a weather station located near the experimental site. 


\subsection{Statistical Analysis}

The study design was a Randomized Complete Block with six replications. Data were analyzed using the general linear models in SAS (SAS, 2011) by analysis of a variance and means were separated using Fisher's Least Significant Difference Test at $p \leq 0.05$. A linear regression model was fit using PROC REG (SAS, 2011) after contrast analyses indicated a significant $(\mathrm{p} \leq 0.05)$ response.

\section{RESULTS}

\subsection{Weather Conditions}

Monthly average temperature, precipitation and average from the 30-yr average are shown in Table $\mathbf{1}$. The average air temperature during the soybean growing seasons in each year was generally similar to the 30 -yr average, except for June and July 2011 and August 2012 when temperature was $2.3,1.3$ and $1.1^{\circ} \mathrm{C}$ higher and October 2011 and June 2012 when temperature was 2.3 and $1.4^{\circ} \mathrm{C}$ lower, respectively.

Total precipitation was $151 \mathrm{~mm}$ higher during soybean growing season in 2011 and $15 \mathrm{~mm}$ higher in 2012. Insufficient precipitation was observed in June in two years and also July, September and October in 2012. Compared to multiyear rainfall data, higher precipitation was observed in August of 2011 and 2012 and July, September and October of 2011.

\subsection{Normalized Difference Vegetation Index (NDVI)}

Table 2 shows that plant NDVI at 7 weeks after planting significantly increased by $10.5 \%$ with application of polymer seed coating treatment at 395 $\mathrm{mL} 100 \mathrm{~kg} \mathrm{seeds}{ }^{-1}$ compared to control. Plant NDVI was also significantly greater at 8 (10.2 and $10.8 \%)$ and 10 (4.6 and 4.2\%) weeks following planting with applications of seed treatments at $265 \mathrm{~mL}$ and $395 \mathrm{~mL}$ $100 \mathrm{~kg} \mathrm{seeds}{ }^{-1}$, respectively. Polymer seed coating with micronutrients did not significantly affect plant NDVI at 4, 5, 6 and 9 weeks after soybean planting.

\subsection{Plant Leaf Area Index (LAI), Height, Seed Weight and Grain Yield}

Compared to the untreated control, application of polymer seed coating at 265 and $395 \mathrm{~mL} 100 \mathrm{~kg} \mathrm{seeds}^{-1}$ significantly increased soybean yields by $8.1 \%$ and $14.0 \%$, respectively (Table 3 ).

Although there was no significant difference, plant LAI improved by 2.0 and $1.5 \%$ over control at 8 weeks after soybean planting and 6.9 and $5.3 \%$ at 12 weeks following planting with application of seed coating at $265 \mathrm{~mL}$ and $395 \mathrm{~mL} 100 \mathrm{~kg} \mathrm{seeds}{ }^{-1}$, respectively. Compared to control, application of seed coating at $265 \mathrm{~mL}$ and $395 \mathrm{~mL} 100 \mathrm{~kg} \mathrm{seeds}^{-1}$ increased plant height by 3.5 and $4.8 \%$, respectively, but difference was not significant.

Table 1. Monthly average air temperature and precipitation during soybean growth near Blackville, SC from 2011 to 2012

\begin{tabular}{|c|c|c|c|c|c|c|}
\hline \multirow[b]{2}{*}{ Year } & \multicolumn{6}{|c|}{ Month } \\
\hline & June & July & Aug. & Sep. & Oct. & Average/Total \\
\hline \multicolumn{7}{|c|}{$\overline{\text { Temperature }\left({ }^{\circ} \mathrm{C}\right)}$} \\
\hline 2011 & 27.4 & 28.0 & 18.0 & 23.2 & 15.9 & 21.3 \\
\hline 2012 & 23.8 & 27.7 & 18.8 & 22.7 & 18.4 & 21.9 \\
\hline 30-yr avg. & 25.2 & 26.8 & 17.8 & 23.4 & 18.2 & 21.6 \\
\hline \multicolumn{7}{|c|}{ Precipitation (mm) } \\
\hline 2011 & 58.0 & 140.0 & 182 & 142.0 & 111.0 & 575.0 \\
\hline 2012 & 80.0 & 97.0 & 309 & 19.0 & 14.0 & 439.0 \\
\hline $30-y r$ avg & 129.0 & 130.0 & 122 & 92.0 & 80.0 & 524.0 \\
\hline
\end{tabular}

Table 2. Influence of $45 \%$ seed coating polymer formulations with Copper $(\mathrm{Cu})$, Manganese $(\mathrm{Mn})$ and $\mathrm{Zinc}(\mathrm{Zn})$ mixture on plant Normalized Difference Vegetation Index (NDVI) at 4 through 10 weeks following planting of soybeans near Blackville, SC from 2011 to 2012

\begin{tabular}{|c|c|c|c|c|c|c|c|}
\hline \multirow{2}{*}{$\begin{array}{l}\text { Formulation rate } \\
\left(\mathrm{mL} 100 \mathrm{~kg} \mathrm{seeds}^{-1}\right)\end{array}$} & \multicolumn{7}{|c|}{ Normalized Difference Vegetation Index (NDVI) (weeks after planting) } \\
\hline & 4 & 5 & 6 & 7 & 8 & 9 & 10 \\
\hline Control & 0.5616 & 0.5900 & 0.7423 & 0.6896 & 0.7582 & 0.8621 & 0.8649 \\
\hline $265 \mathrm{~mL}$ & 0.5730 & 0.6405 & 0.7490 & 0.6444 & 0.8354 & 0.8789 & 0.9048 \\
\hline $395 \mathrm{~mL}$ & 0.5504 & 0.6540 & 0.7495 & 0.7621 & 0.8403 & 0.8867 & 0.9008 \\
\hline $\operatorname{LSD}_{(0.05)}$ & NS & NS & $\mathrm{NS}$ & 0.0598 & 0.0474 & NS & 0.0289 \\
\hline
\end{tabular}


Table 3. Influence of $45 \%$ seed coating polymer formulations with Copper $(\mathrm{Cu})$, Manganese $(\mathrm{Mn})$ and $\mathrm{Zinc}(\mathrm{Zn})$ mixture on Leaf Area Index (LAI) at 8 and 12 weeks after planting, plant height, weight of 100 seeds and grain yield of soybeans near Blackville, SC from 2011 to 2012

\begin{tabular}{llllll}
\hline $\begin{array}{l}\text { Formulation rate } \\
\left(\mathrm{mL} 100 \mathrm{~kg} \mathrm{seeds}^{-1}\right)\end{array}$ & $\begin{array}{l}\text { LAI }(8 \text { weeks } \\
\text { after planting) }\end{array}$ & $\begin{array}{l}\text { LAI (12 weeks } \\
\text { after planting) }\end{array}$ & $\begin{array}{l}\text { Plant } \\
\text { height }(\mathrm{cm})\end{array}$ & $\begin{array}{l}\text { 100 seed } \\
\text { weight }(\mathrm{gms})\end{array}$ & $\begin{array}{l}\text { Grain yield } \\
(\mathrm{Mg} \mathrm{ha})\end{array}$ \\
\hline Control & 1.96 & 4.32 & 73.3 & 12.6 & 1.86 \\
$265 \mathrm{~mL}$ & 2.00 & 4.62 & 75.9 & 12.2 & 2.01 \\
$395 \mathrm{~mL}$ & 1.99 & 4.55 & 76.8 & 12.7 & 2.12 \\
$\mathrm{LSD}_{(0.05)}$ & NS & NS & NS & NS & 0.15 \\
\hline
\end{tabular}

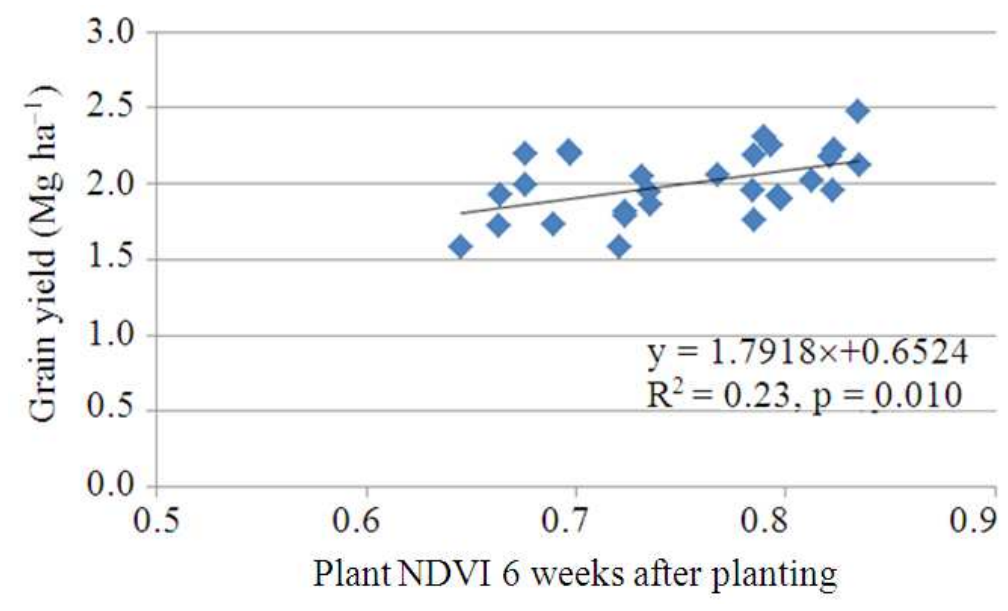

Fig. 1. Relationship between plant Normalized Difference Vegetation Index (NDVI) at 6 weeks after planting and grain yield of soybeans from 2011 to 2012

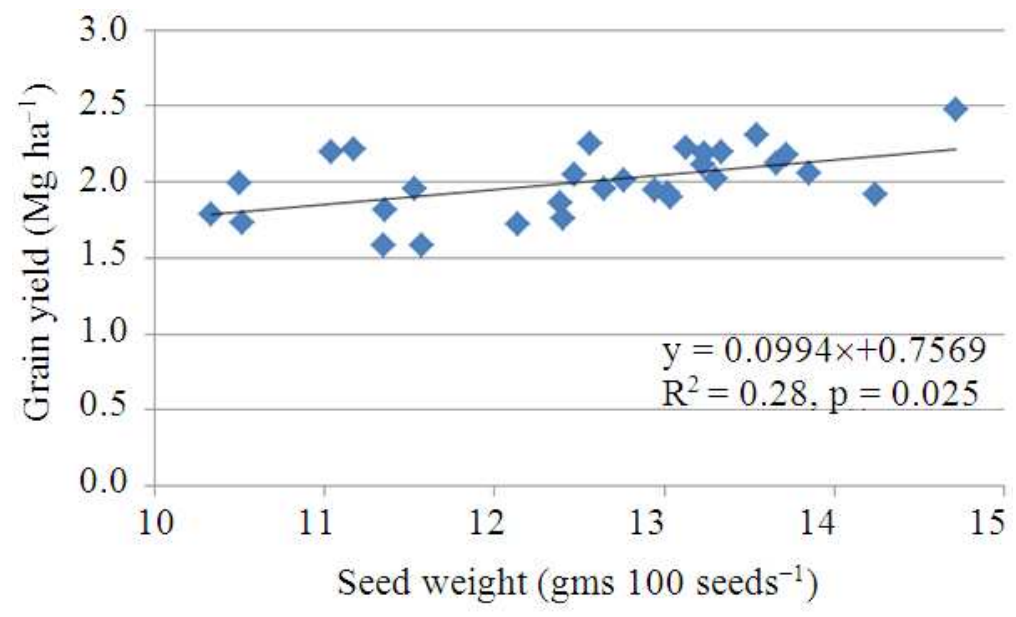

Fig. 2. Relationship between weight of 100 seeds and grain yield of soybeans from 2011 to 2012

\subsection{Relationships between Grain Yields and Plant Parameters}

Significant relationships were observed between grain yield and plant NDVI at 6 weeks following planting and seed weight (Fig. 1 and 2). Based on linear relationship, increasing plant NDVI by 0.1 at 6 weeks after planting soybeans increased yields by $179.2 \mathrm{~kg}$ $\mathrm{ha}^{-1}$. Also, grain yields increased by $99.4 \mathrm{~kg} \mathrm{ha}^{-1}$ with increasing weight of 100 seeds by $1 \mathrm{~g}$.

\section{DISCUSSION}

Previous research on polymer seed coating with micronutrients was limited and not conclusive. Han et al. (2011) indicated that soybean growth was generally 
positively correlated with $\mathrm{Zn}$ concentrations. Application of $\mathrm{Zn}$ also improved wheat growth (Nadim et al., 2012). Results from this study showed that polymer seed coating with micronutrients increased plant NDVI by $10.5 \%$ at $395 \mathrm{~mL} 100 \mathrm{~kg}$ seeds $^{-1}, 10.2$ and $10.8 \%$ at 8 weeks and 4.6 and $4.2 \%$ at 10 weeks after planting soybeans at $265 \mathrm{~mL}$ and 395 $\mathrm{mL} 100 \mathrm{~kg} \mathrm{seeds}^{-1}$, respectively.

Researchers reported that higher wheat Leaf Area Index (LAI) were obtained with $\mathrm{Zn}$ applications (Nadim et al., 2012) and production of sorghum and wheat was positively correlated with micronutrient levels in the soil (Nandapure et al., 2011). Inocencio et al. (2012) observed that $\mathrm{Zn}$ applications improved yields of soybeans, even when micronutrient availability in the soil was above the critical level. Wiatrak (2013) reported higher grain yields with application of polymer seed coating with micronutrients to winter wheat. According to Arshad et al. (2011), grain yield of wheat increased with $\mathrm{Cu}$ and $\mathrm{Zn}$ application. Applications of $\mathrm{Zn}, \mathrm{Fe}$ and $\mathrm{Mn}$ improved yields of susceptible wheat cultivars (Narwal et al., 2012). This study showed that polymer seed coating at $265 \mathrm{~mL}$ and $395 \mathrm{~mL} 100 \mathrm{~kg}$ seeds $^{-1}$ significantly increased soybean yields by 8.1 and $14.0 \%$, respectively. However, plant height prior to harvest and LAI were not affected by seed coating.

A positive relationship between plant NDVI during crop vegetation and grain yields in this study agrees with Raun at al. (2001), who observed strong relationship between these parameters in winter wheat. Moreover, a positive relationship was observed between weight of grain and soybean grain yields.

\section{CONCLUSION}

This study investigated the effects of two polymer seed coating application rates on growth and yield of soybeans grown under dryland conditions. Application of seed coating to seeds at $265 \mathrm{~mL} 100 \mathrm{~kg}$ seeds $^{-1}$ improved plant NDVI by $10.5 \%$ and applications of $285 \mathrm{~mL}$ and $395 \mathrm{~mL} 100 \mathrm{~kg} \mathrm{seeds}{ }^{-1}$ improved plant NDVI by 10.2 and $10.8 \%$ at 8 weeks after planting soybeans and 4.6 and $4.2 \%$ over control at 10 weeks after planting crop. Treatments did not affect plant NDVI at 4 through 6 weeks and 9 weeks after planting.

Grain yields significantly increased by $8.1 \%$ and $14.0 \%$ with application of polymer seed coating at 265 and $395 \mathrm{~mL} 100 \mathrm{~kg}$ seeds $^{-1}$ compared to the untreated control. Although no significant difference was observed between treatments, applications of seed coating at $265 \mathrm{~mL}$ and $395 \mathrm{~mL} 100 \mathrm{~kg} \mathrm{seeds}^{-1}$ improved plant LAI by 2.0 and $1.5 \%$ at 8 weeks following planting soybeans and 6.9 and $5.3 \%$ at 12 weeks after planting, respectively. Moreover, plant height increased by 3.5 and $4.8 \%$ over untreated control with application of seed coating at $265 \mathrm{~mL}$ and $395 \mathrm{~mL} 100 \mathrm{~kg} \mathrm{seeds}{ }^{-1}$, respectively. Significant positive linear relationship showed that increasing plant NDVI by 0.1 increased crop yield by $179.2 \mathrm{~kg}$ $\mathrm{ha}^{-1}$ and weight increase by $1 \mathrm{~g}$ of $100 \mathrm{seeds}^{-1}$ increased grain yield of soybeans by $99.4 \mathrm{~kg} \mathrm{ha}^{-1}$. Future research may focus on evaluating more micronutrients and different concentrations on crop growth and yields.

\section{ACKNOWLEDGEMENT}

I greatly appreciate a financial support from Specialty Fertilizer Products (SFP) for conducting field research.

\section{REFERENCES}

Anthony, P., G. Malzer, M.C. Zhang and S. Sparrow, 2012 b. Soil nitrogen and phosphorus behavior in a long-term fertilization experiment. Agron. J., 104: 1223-1237. DOI: 10.2134/agronj2012.0020

Anthony, P., G. Malzer, S. Sparrow and M. Zhang, 2012a. Soybean yield and quality in relation to soil properties. Agron. J., 104: 1443-1458. DOI: 10.2134/agronj2012.0095

Arshad, M., G. Murtaza, M.A. Ali, M. Shafiq and C. Dumat et al., 2011. Wheat growth and phytoavailability of copper and zinc as affected by soil texture in saline-sodic conditions. Pakis. J. Bot., 43: 2433-2439.

Ciolek, A., E. Makarska, M. Wesolowski and R. Cierpiala, 2012. Content of selected nutrients in wheat, barley and oat grain from organic and conventional farming. J. Element., 17: 181-189. DOI: $10.5601 /$ jelem.2012.17.2.02

De Figueiredo, C.C., D.V. Barbosa, S.A. De Oliveira, M. Fagioli and J.H. Sato, 2012. Polymer-coated phosphate fertilizer and liming on the production and morphological parameters of corn. Rev. Cienc. Agron., 43: 446-452. DOI: 10.1590/S180666902012000300005

Eleiwa, M.E., E.R. Hamed and H.S. Shehata, 2012. Biofertilizers and/or some micronutrients role on wheat plants grown on newly reclaimed soil. Afric. J. Ecol., 50: 464-475. DOI: 10.1111/j.13652028.2012.01342.x 
Gesch, R.W., D.W. Archer and K. Spokas, 2012. Can using polymer-coated seed reduce the risk of poor soybean emergence in no-tillage soil? Field Crops Res., 125: 109-116. DOI: 10.1016/j.fcr.2011.09.005

Ghandilyan, A., U.B. Kutman, B.Y. Kutman, I. Cakmak and M.G.M. Aarts, 2012. Genetic analysis of the effect of zinc deficiency on Arabidopsis growth and mineral concentrations. Plant Soil, 361: 227-239. DOI: $10.1007 / \mathrm{s} 11104-012-1334-0$

Goncalves, A.C., J.H. Nacke, D. Schwantes, I.A. Nava and L. Strey, 2011. Phytoavailability of toxic heavy metals and productivity in wheat cultivated under residual effect of fertilization in soybean culture. Water Air Soil Pollut., 220: 205-211. DOI: 10.1007/s11270-011-0747-3

Guareschi, R.F., P.R. Gazolla, A. Perin and J.M.K. Santini, 2011. Antecipated fertilization on soybean with triple superphosphate and potassium chloride coated with polymers. Cienc. Agrotecnol., 35: 643-648. DOI: 10.1590/S141370542011000400001

Han, X.Z., X.H. Li, N. Uren and C.X. Tang, 2011. Zinc fractions and availability to soybeans in representative soils of Northeast China. J. Soils Sedim., 11: 596-606. DOI: 10.1007/s11368-0110336-5

Hassan, H.M., P. Marschner, A. McNeill and C.X. Tang, 2012. Grain legume pre-crops and their residues affect the growth, $\mathrm{P}$ uptake and size of $\mathrm{P}$ pools in the rhizosphere of the following wheat. Biol. Fert. Soils, 48: 775-785. DOI: 10.1007/s00374-012-0671-8

Hitsuda, K., K. Toriyama, G.V. Subbarao and O. Ito, 2010. Percent relative cumulative frequency approach to determine micronutrient deficiencies in soybean. Soil Sci. Soc. Am. J., 74: 2196-2210. DOI: 10.2136/sssaj2010.0158

Inocencio, M.F., A.V. De Resende, A.E.F. Neto, M.P. Veloso and F.M. Ferraz et al., 2012. Soybean response to zinc fertilization in soil with contents above critical level. Pesq. Agropec. Brasileira, 47: 1550-1554. DOI: $\quad 10.1590 / \mathrm{S} 0100-$ 204X2012001000020

Kobraee, S. and K. Shamsi, 2011a. Determination of zinc, iron and manganese concentration and partitioning during reproductive stages of soybean grown under field conditions. Res. Crops, 12: 752-760.

Kobraee, S. and K. Shamsi, 2011b. Measurement of zinc, iron and manganese ratios in different parts of soybean plant. Res. Crops, 12: 761-765.
Konkol, N.R., C.J. McNamara, K. Bearce-Lee, H. Kunoh and R. Mitchell, 2012. Novel method of micronutrient application increases radish (Raphanus sativus) and shirona (Brassica rapa var. Pekinensis) biomass. J. Plant Nutr., 35: 471479. DOI: 10.1080/01904167.2012.639925

Moosavi, A.A. and A. Ronaghi, 2011. Influence of foliar and soil applications of iron and manganese on soybean dry matter yield and iron-manganese relationship in a calcareous soil. Aust. J. Crop. Sci., 5: 1550-1556.

Nadim, M.A., I.U. Awan, M.S. Baloch, E.A. Khan and K. Naveed et al., 2012. Response of wheat (Triticum aestivum L.) to different micronutrients and their application methods. J. Anim. Plant Sci., 22: 113119.

Nandapure, S.P., B.A. Sonune, V.V. Gabhane, R.N. Katkar and R.T. Patil, 2011. Influence of long term fertilization on micronutrients availability, their uptake and productivity of sorghum-wheat sequence under semi-arid condition on a vertisol. Crop Res. (Hisar), 42: 35-39.

Narwal, R.P., R.R. Dahiya, R.S. Malik and R. Kala, 2012. Influence of genetic variability on zinc, iron and manganese responses in wheat. J. Geochem. Exp., 121: 45-48. DOI: 10.1016/j.gexplo.2012.06.006

Raun, W.R., J.B. Soile, G.V. Johnson, M.L. Stone and E.V. Lukina et al., 2001. In-season prediction of potential grain yield in winter wheat using canopy reflectance. Agron. J., 93: 131-138. DOI: 10.2134/agronj2001.931131x

SAS, 2011. SAS/STAT 9. 3 User's Guide: Survey Data Analysis. 1st Edn., SAS Institute Inc., Cary, NC., ISBN-10: 1607649195, pp: 668.

Wang, C., Z.F. Yang, X.Y. Yuan, P. Browne, L.X. Chen and J.F. Ji, 2013. The influences of soil properties on $\mathrm{Cu}$ and $\mathrm{Zn}$ availability in soil and their transfer to wheat (Triticum aestivum L.) in the Yangtze River delta region, China. Geoderma, 193: 131-139. DOI: 10.1016/j.geoderma.2012.10.004

Wiatrak, P., 2013. Infuence of seed coating with micronutrients on growth and yield of winter wheat in Southeastern Coastal Plains. Am. J. Agric. Biol. Sci., $\quad$ 8: 230-238. DOI: 10.3844/ajabssp.2013.230.238

Wozniak, A. and B. Makarski, 2012. Content of minerals in grain of spring wheat cv. Koksa depending on cultivation conditions. J. Element., 17: 517-523. DOI: $10.5601 /$ jelem.2012.17.3.13 
Xie, W.J., J.M. Zhou, H.Y. Wang, Q. Liu and J.B. Xia et al., 2011. $\mathrm{Cu}$ and $\mathrm{Pb}$ accumulation in maize (Zea mays L.) and soybean (Glycine max L.) as affected by N, P and K application. Afr. J. Agric. Res., 6: 1469-1476.
Zhang, Y.Q., Y. Deng, R.Y. Chen, Z.L. Cui and R. Yost et al., 2012. The reduction in zinc concentration of wheat grain upon increased phosphorus-fertilization and its mitigation by foliar zinc application. Plant Soil, 361: 143-152. DOI: $10.1007 / \mathrm{s} 11104-012-1238-\mathrm{z}$ 